Check for updates

Cite this: Nanoscale Adv., 2020, 2, 286

\title{
The effect of $\mathrm{ZnO} / \mathrm{ZnSe}$ core/shell nanorod arrays photoelectrodes on $\mathrm{PbS}$ quantum dot sensitized solar cell performance
}

\author{
M. Kamruzzaman iD
}

ZnO nanorod (NR) based inorganic quantum dot sensitized solar cells have gained tremendous attention for use in next generation solar cells. $\mathrm{ZnO} / \mathrm{ZnSe}$-core/shell NR arrays (NRAs) with various densities were grown on an Au@ZnO seed layer ( $\mathrm{Au}=0.0,4.0,8.0$ and $16.0 \mathrm{~nm}$ ) on glass supported fluorine-doped tin oxide (FTO) substrates using low cost hydrothermal and ion-exchange approaches. PbS quantum dots (QDs) were loaded into the $\mathrm{ZnO} / \mathrm{ZnSe}$ core/shell NRAs via a successive ionic layer adsorption and reaction (SILAR) method. The morphology, structural and optical properties of the core/shell NRAs were investigated using field emission scanning electron microscopy (FE-SEM), transmission electron microscopy (TEM), X-ray diffraction (XRD) and UV-vis spectroscopy measurements. It was observed that the density of the $\mathrm{ZnO} / \mathrm{ZnSe}$ NRAs decreases with increasing Au buffer layer thickness. The absorption decreases along with a decrease in the ZnO/ZnSe NRA density. The ZnO NRs/PbS QD photoelectrode performs poorly; however, after introducing a ZnSe shell on the core-ZnO, the solar cells parameters changed according to the $\mathrm{ZnO} / \mathrm{ZnSe} N R A$ density. Values of $\eta=\sim 0.88 \%, \mathrm{~J}_{\mathrm{SC}}=14.60 \mathrm{~mA} \mathrm{~cm}{ }^{-2}$, and $V_{\mathrm{OC}}$ $=190 \mathrm{mV}$, and $\eta=\sim 0.25 \%, J_{\mathrm{SC}}=6.77 \mathrm{~mA} \mathrm{~cm}^{-2}$, and $V_{\mathrm{OC}}=115 \mathrm{mV}$ were obtained for the highest and lowest NRA densities, respectively. Although the photovoltaic performance of these photoelectrodes is still inferior, further improvement of the device would be possible by suppressing surface defects, and through quality optimization of the $\mathrm{ZnO} / \mathrm{ZnSe} \mathrm{NRAs}$, PbS QDs, counter electrode and electrolyte.

Received 20th August 2019 Accepted 13th November 2019

DOI: 10.1039/c9na00523d

rsc.li/nanoscale-advances

\section{Introduction}

Quantum dot (QD) sensitized nanostructure based solar cells have been attracting a tremendous amount of attention in the development of an alternative to silicon-based solar cells. ${ }^{1}$ Inorganic quantum dot solar cells (QDSSCs) are promising for next generation solar cells due to their low-cost cell fabrication and high power conversion efficiency. ${ }^{2-12}$ This type of photovoltaic cell is a modification of the dye synthesized solar cell (DSSC) ${ }^{13,14}$ which was first introduced by O'Regan and Grätzel in $1991{ }^{14}$ The efficiencies of QDSSCs are lower than those of DSCs, ${ }^{15}$ which implies that some challenges still remain in enhancing the performance of QDSSCs. The power conversion efficiency (PCE) of these solar cells has risen to over $11.6 \%{ }^{16-23}$ QDSSCs are more attractive than DSSCs due to the fact that QDs are promising efficient light harvesting candidate materials for sensitized solar cells. ${ }^{24}$ QDs have been used as a sensitizer due to them having several excellent properties such as; that their band gap can be tuned via a size dependent quantum confinement effect, ${ }^{25}$ they have higher absorption coefficients, ${ }^{26}$ multiple exciton generation (MEG), ${ }^{27}$ the possibility of hot electron injection, ${ }^{28}$ extended photostability, impact ionization

Department of Physics, Begum Rokeya University, Rangpur, Rangpur-5400, Bangladesh. E-mail: kzaman.phy11@gmail.com; Tel: +880-1771034439 effects and simple fabrication processes. ${ }^{29}$ Various narrow band gap inorganic semiconductors QDs such as $\mathrm{CdS},{ }^{30} \mathrm{CdSe},{ }^{31}$ CdHgTe, ${ }^{32}$ InAs, ${ }^{32}$ CISeS, ${ }^{33} \mathrm{Zn}-\mathrm{Cu}-\mathrm{In}-\mathrm{Se},{ }^{16} \mathrm{CdTe}^{34}$ and $\mathrm{PbS}^{35}$ have been used as sensitizers. C. Y. Luan et al. and Lee et al. reported efficiencies of $0.27 \%$ and $0.59 \%$ for CdS QD-sensitized ZnO NR-based solar cells. ${ }^{30,36}$ The efficiency of CdSe QDsensitized $\mathrm{ZnO}$ nanotube array based solar cells is around $0.44 \% .^{31} \mathrm{TiO}_{2}$ nanostructured solar cells decorated with CdHgTe QDs and InAs QDs exhibit PCEs of around $0.81 \%{ }^{31}$ and $0.3 \%,{ }^{32}$ respectively. $\mathrm{CuInSe}_{x} \mathrm{~S}_{2-x}$ and $\mathrm{Zn}-\mathrm{Cu}-\mathrm{In}-\mathrm{Se}$ QD sensitized solar cells have efficiencies of around $5 \%{ }^{33}$ and $11.61 \%{ }^{16}$ The efficiencies of core/shell CdSe/CdTe and CdTe/CdSe structures have been reported to be around $0.14 \%$ and $\sim 0.38 \%{ }^{34}$ The PCE of a PbS QD sensitized $\mathrm{TiO}_{2}$ nanoparticle thin film solar cell was found to be $3.88 \% .{ }^{34}$ Baxter and Aydil have reported an efficiency of $0.5 \%$ for a $\mathrm{ZnO} \mathrm{NW}$-based solar cell. ${ }^{37} \mathrm{~A}$ vertical oriented $\mathrm{ZnO} \mathrm{NR}$ based hybrid-polymer/ZnO photovoltaic device demonstrated an efficiency of $0.2 \%{ }^{38}$ An efficiency of $0.22 \%$ has been reported for a ZnO NR-based dye-synthesized solar cell. ${ }^{39}$ Recently, wide band gap metal oxides QDs have also been used to improve charge transfer properties and reduce the charge recombination rate. ${ }^{16}$ In addition, QD sensitized solar cell devices can be printed in a roll-to-roll manner using compatible techniques. Among the various QDs, lead sulfide ( $\mathrm{PbS}$ ) QDs have been chosen as a sensitizer for the 
development of photo-energy conversion efficiency ${ }^{25-35,40}$ and photodetector performance ${ }^{32}$ because of their unique properties such as size-dependent tunable band gap in between 0.41 (bulk) and $4.0 \mathrm{eV}^{34,40}$, multiple exciton generation (MEG), ${ }^{41}$ high absorption coefficient and good photostability. PbS QDs exhibit strong quantum size effects compared to CdS and CdSe QDs ${ }^{29}$ for a QD size of $<18 \mathrm{~nm}$.

To construct QD-sensitized solar cells, a general strategy is essential to design and select new materials as well as novel nanostructures for electron transporting and QD loading. In this case surface morphologies play a crucial role in improving electron mobility associated with ordered metal oxide nanostructures. The nanostructures of $\mathrm{SnO}_{2}, \mathrm{TiO}_{2}, \mathrm{WO}_{3}$ and $\mathrm{ZnO}$ metal oxides have been studied for several years. Among these oxides, the nanostructures of $\mathrm{TiO}_{2}$ and $\mathrm{ZnO}$ have been extensity and intensively investigated. ${ }^{42-48}$ Although $\mathrm{TiO}_{2}$ possesses an almost similar band gap and physical properties as those of $\mathrm{ZnO}, \mathrm{ZnO}$ is the most suitable semiconductor material for photoanode applications. ${ }^{44-48}$ One dimensional (1D) ZnO NRs/ NWs exhibit much higher electron mobility $\left(155 \mathrm{~cm}^{2} \mathrm{~V}^{-1} \mathrm{~s}^{-1}\right.$ vs. $10^{-5} \mathrm{~cm}^{2} \mathrm{~V}^{-1} \mathrm{~s}^{-1}$ ) and large exciton diffusion lengths, ${ }^{49}$ low sensitivity to UV degradation and long term stability, which means that $\mathrm{ZnO}$ is a good alternative material to $\mathrm{TiO}_{2}{ }^{43}$ Importantly, the nanostructures and morphology of $\mathrm{ZnO}$ can be simply controlled..$^{50}$ A $1 \mathrm{D} \mathrm{ZnO}-\mathrm{NR} / \mathrm{NW}$ nanostructure provides a direct pathway for the carrier transportation of photoinduced electrons if it is used as a photoanode, which might suppress charge recombination ${ }^{51-53}$ and hence the efficiency can be improved via the utilization of controllable nanostructured arrays. Furthermore, the infiltration of tunable size QDs in nanostructures can effectively improve the photovoltaic PCE. ${ }^{50,54-58}$ However, the performance of QDSSCs not only depends on the photoanode and QDs, but also on the counter electrode (CE) as well as on the electrolyte. The CE is an important issue in the development of efficient QDSSCs. Electrolyte improvement is needed to overcome the poor charge transfer of the CE to the oxidized redox electrolyte species, which greatly affects the fill factor and PCE.

In this report, $\mathrm{ZnO} / \mathrm{ZnSe}$ core/shell $\mathrm{NR}$ arrays with various densities have been grown via hydrothermal and ion exchange approaches for QDSSC applications. The PbS QDs are loaded in the pores and/or on the walls of the vertically oriented $\mathrm{ZnO} / \mathrm{ZnSe}$ core/shell NR arrays to increase the mobility of the carriers. ${ }^{58,59}$ $\mathrm{Cu}_{2} \mathrm{~S}$ is used as a CE due to its superior performance in QDSSCs, in terms of its low cost, facile fabrication, high electrocatalytic activity and good stability. On the other hand, an electrolyte that operates via a polysulfide redox couple $\left(\mathrm{S}_{n}{ }^{2-} / \mathrm{S}^{2-}\right)$ is used for testing device performance owing to the effective stabilization of QDs and to improve the performance of QDSSCs. ${ }^{57,60}$

The purpose of this work is to investigate the effect of the physical properties of various densities of $1 \mathrm{D} \mathrm{ZnO} / \mathrm{ZnSe}$ core/ shell NRAs on photoelectrode performance. Firstly, ZnO (core) $\mathrm{NR}$ arrays were synthesized on a modified Au@ZnO seed layer $(\mathrm{Au}=0.0,4.0,8.0$ and $16.0 \mathrm{~nm})$ via a hydrothermal approach and then $\mathrm{ZnO}$ (core) was coated with a ZnSe shell via an ion exchange approach consisting of $\mathrm{ZnO} / \mathrm{ZnSe}$ (core/shell) NRAs. The ZnSe shell is used to enhance the optical absorption attributed to reducing the band gap and enhancing the surface area for accommodating more QDs. As a sensitizer, PbS QDs infiltrate into the NRAs to enhance the light harvesting properties of the $\mathrm{ZnO} / \mathrm{ZnSe}$ photoelectrode. A detailed synthesis process, characterization, and photoelectric performance of the photoelectrodes are discussed.

\section{Experimental}

The substrate cleaning, ZnO seed layer preparation and ZnO NR arrays growth have been described in previous papers. ${ }^{\mathbf{8}, 9,58,61}$ Briefly, a seed layer was prepared on cleaned glass supported fluorine-doped tin oxide (FTO) substrates via a spin coating method. A sol gel solution of zinc acetate dehydrate $(0.03 \mathrm{M})$ and ethanolamine $(0.03 \mathrm{M})$ was spin coated on the substrates at $2500 \mathrm{rpm}$ for $1 \mathrm{~min}$ and the film was dried at a temperature of $200{ }^{\circ} \mathrm{C}$. The process was repeated twice followed by thermal annealing at $400{ }^{\circ} \mathrm{C}$ for $30 \mathrm{~min}$. Buffer layers of $\mathrm{Au}(0.0,4.0,8.0$, and 16.0) $\mathrm{nm}$ were deposited on the $\mathrm{ZnO}$ seed layer via a thermal evaporation method under a pressure of $2.2 \times 10^{-6}$ Torr. The modified Au@ZnO seed layers were then annealed at $350{ }^{\circ} \mathrm{C}$ for $30 \mathrm{~min}$. After that, the modified seed layer substrates were suspended face down in an equimolar concentration $(0.025 \mathrm{M})$ of an aqueous solution of zinc nitrate hexahydrate and hexamethylenetetramine (HMTA) at a temperature of $90^{\circ} \mathrm{C}$ for $5 \mathrm{~h}$. The process was repeated six times to grow the desired NR arrays. The final ZnO NR array products were annealed in the air at $350{ }^{\circ} \mathrm{C}$ for 30 minutes to remove inorganic salts or impurities and to improve crystallinity. Then, the $\mathrm{ZnO} / \mathrm{ZnSe}$ core/shell NR arrays were synthesized by immersing ZnO NR arrays in a mixture of an aqueous solution of Se powder and $\mathrm{NaBH}_{4}(8 \mathrm{~mm})$ at $55{ }^{\circ} \mathrm{C}$ for $3 \mathrm{~h}$. The process was repeated for a second time to obtain a ZnSe shell with the desired thickness. After that, PbS QDs were loaded onto the $\mathrm{ZnO} / \mathrm{ZnSe}$ NR core/ shell NR arrays via a successive ionic layer adsorption and reaction (SILAR) method. Firstly, a ZnO/ZnSe NR core/shell was dipped into a $0.1 \mathrm{M}$ lead nitrate $\mathrm{Pb}\left(\mathrm{NO}_{3}\right)$ aqueous solution for $1 \mathrm{~min}$ to form $\mathrm{Pb}^{2+}$ ions and then a further 1 min into a $0.1 \mathrm{M}$ sodium sulfide $\left(\mathrm{Na}_{2} \mathrm{~S}\right)$ aqueous solution to allow $\mathrm{S}^{2-}$ to react with the pre-adsorbed $\mathrm{Pb}^{2+}$, leading to the formation of $\mathrm{PbS}$ QDs. The procedure was repeated 5 times and the substrate was rinsed with deionized (DI) water between the dips.

To produce the final ZnO NR, ZnO/ZnSe core/shell NR array and PbS QD, the following chemical reactions eqn (1)-(3) were took place: ${ }^{58,62-64}$

$$
\begin{gathered}
\mathrm{Zn}\left(\mathrm{NO}_{3}\right) \cdot 6 \mathrm{H}_{2} \mathrm{O}+\left(\mathrm{CH}_{2}\right) 6 \mathrm{~N}_{4} \leftrightarrow \mathrm{ZnO}+\mathrm{H}_{2} \mathrm{O} \\
\mathrm{Se}+2 \mathrm{NaBH}_{4}^{-}+\mathrm{H}_{2} \mathrm{O} \leftrightarrow \mathrm{ZnSe}+2 \mathrm{OH}^{-}+\mathrm{H}_{2}+2 \mathrm{BNaH}_{3} \\
\mathrm{~Pb}\left(\mathrm{NO}_{3}\right)_{2}+\mathrm{Na}_{2} \mathrm{~S} \cdot 9 \mathrm{H}_{2} \mathrm{O}+\underset{\mathrm{H}}{\mathrm{O}} \leftrightarrow \\
\mathrm{PbS}+2 \mathrm{NaOH}+\mathrm{H}_{2}+7 \mathrm{H}_{2} \mathrm{O}
\end{gathered}
$$

\subsection{Electrolyte}

To investigate the performance of the $\mathrm{ZnO} / \mathrm{ZnSe} / \mathrm{PbS}$ QD photoelectrode, a polysulfide electrolyte was made from aqueous 
solutions of $1.0 \mathrm{M} \mathrm{S}, 0.1 \mathrm{M} \mathrm{NaOH}$, and $1.0 \mathrm{M} \mathrm{Na}_{2} \mathrm{~S}$, which is a good noncorrosive redox couple for QD solar cell devices. ${ }^{58}$ It is used to develop the performance of QDSSCs by reducing the charge recombination between the electrolyte and counter electrode. A low-volatile solvent (DI water) was used to increase the durability of the solar cells. ${ }^{58}$

\subsection{Counter electrode}

A $\mathrm{Cu}_{2} \mathrm{~S}$ counter electrode was prepared by immersing a brass sheet in a $\mathrm{HCl}$ solution (37 wt\%) at a temperature of $70{ }^{\circ} \mathrm{C}$ for $7 \mathrm{~min}$ and subsequently dipping it into a polysulfide aqueous solution of $1.0 \mathrm{M} \mathrm{S}, 0.1 \mathrm{M} \mathrm{NaOH}$, and $1.0 \mathrm{M} \mathrm{Na}_{2} \mathrm{~S}$ for $5 \mathrm{~min}$. It is used as an electron collector to circulate through the external circuit and improve the device performance. ${ }^{58}$

\subsection{Device fabrication}

The solar cells were prepared using two electrodes, $(\mathrm{ZnO} / \mathrm{ZnSe}$ $\mathrm{NRs} / \mathrm{PbS}$ QDs and the counter electrode) separated by a $60 \mu \mathrm{m}$ thick polypropylene spacer, and the internal space of the cells was filled with a polysulfide electrolyte. The active area of each photoelectrode was $0.05 \mathrm{~cm}^{2}$ and the device structure is shown in Fig. 6(a). ${ }^{58}$

\subsection{Characterization}

The nature of the surface of the materials was investigated by field emission scanning electron microscopy (FE-SEM, Philips). The crystallinity and crystal structures of the samples were investigated using X-ray diffraction (XRD, Rigaku Smart) and transmission electron microscopy (TEM, Philips). SEM images were collected using an acceleration voltage of $20 \mathrm{keV}$, spot size of 3 and working distance of $\sim 10 \mathrm{~mm}$. TEM images were collected using a high resolution TEM at $200 \mathrm{keV}$. XRD data were taken in the range of $20^{\circ}$ to $70^{\circ}$ with a step width of $0.02^{\circ}$. UV-vis spectra were collected at RT in the wavelength range of 350 to $1100 \mathrm{~nm}$ (PerkinElmer Lambda). The current density $(J)$-voltage $(V)$ readings were measured with the assistance of air mass 1.5 global (AM1.5G) illuminations apparatus, a calibrated solar simulator with an intensity of $100 \mathrm{~mW} \mathrm{~cm} \mathrm{~cm}^{-2}$ (1-sun).

\section{Results and discussion}

\subsection{X-ray diffraction}

Fig. $1 \mathrm{~A}(\mathrm{a})-(\mathrm{d})$ shows the XRD patterns of the (a) FTO substrate, (b) ZnO NRs, (c) ZnO/ZnSe core/shell and (d) $\mathrm{ZnO} / \mathrm{ZnSe} \mathrm{NRs} / \mathrm{PbS}$ QDs. In this case, the $\mathrm{ZnO} \mathrm{NRs}, \mathrm{ZnO} / \mathrm{ZnSe}$ and $\mathrm{ZnO} / \mathrm{ZnSe} / \mathrm{PbS}$
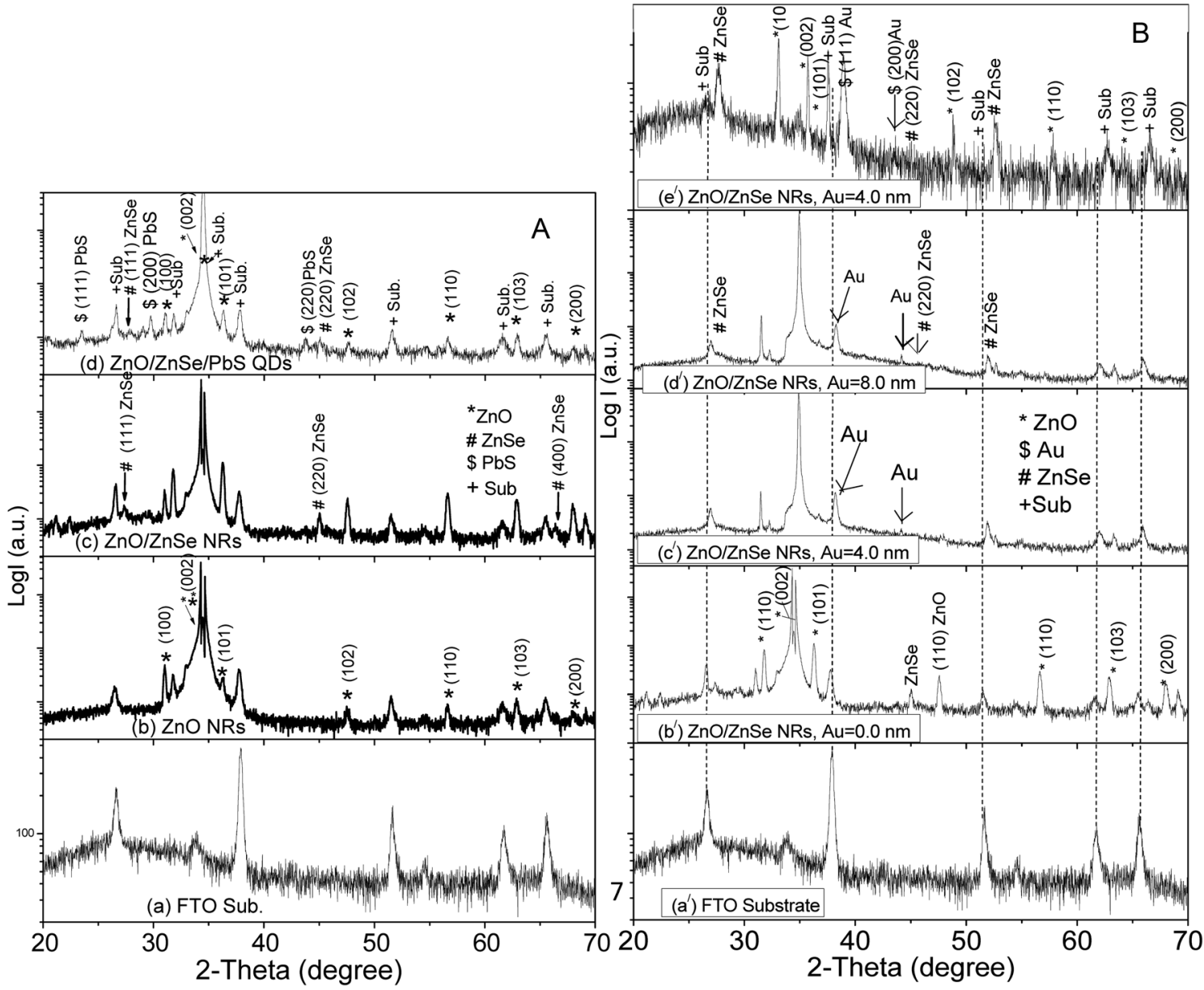

Fig. 1 (A) XRD patterns of the (a) FTO sub., (b) ZnO NRs, (c) ZnO/ZnSe NRs and (d) ZnO/ZnSe/PbS QDs. (B) XRD patterns of the (a') FTO sub., (b') $\mathrm{ZnO} / \mathrm{ZnSe} N R s, \mathrm{Au}=0.0 \mathrm{~nm},\left(c^{\prime}\right) \mathrm{ZnO} / \mathrm{ZnSe} \mathrm{NRs}, \mathrm{Au}=4.0 \mathrm{~nm},\left(\mathrm{~d}^{\prime}\right) \mathrm{ZnO} / \mathrm{ZnSe} \mathrm{NRs}, \mathrm{Au}=8.0 \mathrm{~nm}$ and $\left(\mathrm{e}^{\prime}\right) \mathrm{ZnO} / \mathrm{ZnSe} \mathrm{NRs}, \mathrm{Au}=16.0 \mathrm{~nm} \mathrm{NRAs}$ with various densities. 
were grown on an $\mathrm{Au}$ free $\mathrm{ZnO}$ seed layer, i.e., $\mathrm{Au}=0.0 \mathrm{~nm}$. It can be seen that a few diffraction peaks come from the FTO substrate (Fig. 1A(a)). In Fig. 1A(b), several extra peaks can be observed around the diffraction angles $2 \theta=\sim 31.80^{\circ}, \sim 34.42^{\circ}$, $\sim 36.28^{\circ}, \sim 47.56^{\circ}, \sim 56.66^{\circ}, \sim 62.66^{\circ}$ and $\sim 66.46^{\circ}$. These peaks can be properly indexed as belonging to the (100), (002), (101), (102), (110), (103) and (200) planes, corresponding to hexagonal structured ZnO NRs (JCPDS card no. 036-1451). It is obvious that the intensity of the (002) peak is greater than that of the other peaks, attributed to the preferential vertical orientation along the (002) plane and [0001] direction, normal to the substrate surface. The preferential orientation of $\mathrm{ZnO}$ along the (002) plane can be attributed to the minimum surface free energy, minimum internal stress and high atomic density, which lead to the easy growth of the crystal. ${ }^{65}$ Importantly, some additional peaks in the $\mathrm{ZnO} / \mathrm{ZnSe}$ (Fig. $1 \mathrm{~A}(\mathrm{c})$ ) spectrum associated with $\mathrm{ZnO} \mathrm{NRs}$ (Fig. $1 \mathrm{~A}(\mathrm{~b}))$ at $2 \theta=\sim 27.65^{\circ}, \sim 45.13^{\circ}$ and $\sim 52.67^{\circ}$ correspond to the index planes (111), (220) and (311) for cubic zinc blend structured ZnSe (JCPDS card no. 65-9602). ${ }^{68}$ The appearance of these peaks in the XRD pattern is good evidence for $\mathrm{ZnO} / \mathrm{ZnSe} \mathrm{NR}$ (core/shell) crystal formation and is in good agreement with the TEM image (Fig. 4). Besides these peaks, three additional peaks are observed in the diffraction pattern of $\mathrm{ZnO} / \mathrm{ZnSe} / \mathrm{PbS}$ QDs (Fig. $1 \mathrm{~A}(\mathrm{~d})$ ) at $2 \theta=\sim 23.55^{\circ}$, $\sim 29.58^{\circ}$ and $\sim 43.83^{\circ}$, corresponding to the Miller indices (111), (200) and (220), attributed to the cubic phase of PbS (JCPDS no. 41-1049). Thus, the appearance of these peaks in the XRD patterns suggests that the structure consists of a $\mathrm{ZnO} / \mathrm{ZnSe} / \mathrm{PbS}$ QD photoelectrode.

Fig. 1B shows the XRD patterns of the FTO substrate (Fig. $1 \mathrm{~B}(\mathrm{a} / \mathrm{)})$ and NRAs with various densities of $\mathrm{ZnO} / \mathrm{ZnSe}$ (Fig. $1 \mathrm{~B}(\mathrm{~b} /)-(\mathrm{e} /))$ coupled with an increase in the Au buffer layer thickness $(\mathrm{Au}=0.0,4.0,8.0$ and $16.0 \mathrm{~nm})$. It is interesting that the sharpness of the peaks decreases with increasing buffer layer thickness up to $\mathrm{Au}=8.0 \mathrm{~nm}$, and the peak positions shift toward a higher angle (Fig. $1 \mathrm{~B}(\mathrm{~b} /)-(\mathrm{d} /))$. However, the peaks positions shift significantly for the $\mathrm{Au}=16.0 \mathrm{~nm}$ buffer layer (Fig. 1B(e/)) thickness indicating that a thicker Au buffer layer exerts more stress on $\mathrm{ZnO} / \mathrm{ZnSe} \mathrm{NR}$ growth as a result of NRs not being perfectly grown vertically on the substrate, which is in good agreement with the SEM images (Fig. 3(f)). No peak is visible for $\mathrm{Au}$ in the diffraction pattern of Fig. $1 \mathrm{~B}(\mathrm{~b} /)$, reflecting that the $\mathrm{ZnO} / \mathrm{ZnSe}$ NRAs have grown on the $\mathrm{Au}$ free $\mathrm{ZnO}$ seed layer. However, a few peaks can be seen in the diffraction patterns for $\mathrm{Au}(\mathrm{Fig}$. $1 \mathrm{~B}(\mathrm{c} /)-(\mathrm{e} /)$ ) indicating that these $\mathrm{ZnO} /$ $\mathrm{ZnSe}$ NRAs have grown on the $\mathrm{Au}=0.0 \mathrm{~nm}$ coated $\mathrm{ZnO}$ seed layer. The intensity of the (111) diffraction peak increases with increasing Au buffer layer thickness, which is in good agreement with the SEM images (shown in Fig. 2(b) and (c).) It can be clearly seen that all of the crystallographic planes for the ZnO NRs are still present in all of the diffraction patterns, confirming the existence of wurtzite structured $\mathrm{ZnO} / \mathrm{ZnSe}$ core/shell NRs.

\subsection{Surface morphology measurements using SEM}

Fig. 2(a)-(d) show the surface morphologies of $\mathrm{ZnO}$ seed layers modified by the deposition of $\mathrm{Au}(0.0,4.0,8.0$ and $16.0 \mathrm{~nm})$ buffer layers. It can be clearly seen that the $\mathrm{Au}$ free $\mathrm{ZnO}$ seed layer (Fig. 2(a)) is smoother, uniformly covering the whole substrate surface in a defect free manner with no voids.

After depositing the Au buffer layer on the $\mathrm{ZnO}$ seed layer (Fig. 2(b)-(d)), the samples were annealed at $350{ }^{\circ} \mathrm{C}$ under identical thermal conditions. This led to the formation of nanometer-sized Au grains (clusters), which were dispersed on
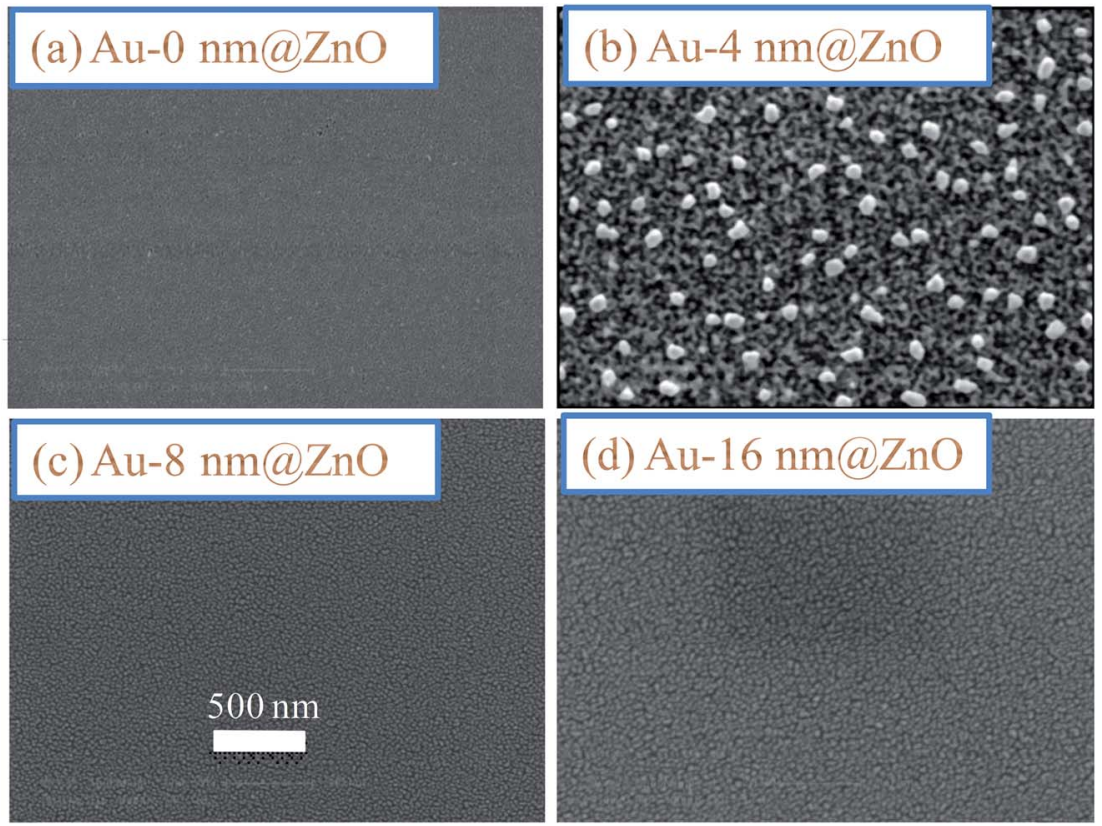

Fig. 2 Surface morphologies of $\mathrm{ZnO}$ seed layers modified with $\mathrm{Au}(0.0,4.0,8.0$ and $16 \mathrm{~nm}$ ) buffer layers: (a) Au-0 nmaZnO, (b) Au-4 nmaZnO, (c) Au-8 nmaZnO, and (d) Au-16 nmaZnO seed layers (scale bar $500 \mathrm{~nm}$ ). 
ZnO seed layer. By comparing the images, it can be seen that there is a large variation in the size distribution of Au grains depending on the thickness of the Au buffer layers. For the $\mathrm{Au}$ $=4.0 \mathrm{~nm}$ thickness, an overall low density of nanograins/ clusters can be observed in the seed surface, attributed to the agglomeration of smaller grains in the thin $\mathrm{Au}$ buffer layer. ${ }^{66}$ As the thickness of the $\mathrm{Au}$ increases, the grains of $\mathrm{Au}$ become noticeably larger and more compacted (Fig. 2(c) and (d)). Such morphology suggests that the Au buffer layers agglomerate into nanosized grains/clusters which play a pivotal role in the controllable growth of $\mathrm{ZnO} / \mathrm{ZnSe} N \mathrm{NAs}$ as is desirable for nanoelectronic and optoelectronic devices.

Fig. 3 shows the surface morphologies and cross-section views of the ZnO NRs (Fig. 3(a)) grown on the Au free ZnO seed layer and $\mathrm{ZnO} / \mathrm{ZnSe}$ core/shell NRAs (Fig. 3(b)-(e)) grown on the Au modified ZnO seeded layers. From Fig. 3(b)-(e), it can be seen that the average core/shell $\mathrm{ZnO} / \mathrm{ZnSe} \mathrm{NR}$ array density $\left(\mu \mathrm{m}^{-2}\right)$ changes considerably with an increase in the Au buffer layer thickness (Au $=0.0$ to $16.0 \mathrm{~nm}$ ), which is in good agreement with previous reports. ${ }^{67-74}$ As the $\mathrm{ZnO}$ seed layers are coated with the $\mathrm{Au}$ buffer layer, the nucleation site of the $\mathrm{ZnO}$ seeds possibly decreases, which might inhibit the growth of $\mathrm{ZnO} / \mathrm{ZnSe}$ NRAs resulting in a decrease in the NR array density. ${ }^{73,74}$ Although the density of the $\mathrm{ZnO} / \mathrm{ZnSe} \mathrm{NR}$ arrays can be controlled, simultaneous control of nanostructure morphology, density, and aspect ratio (length/ diameter) are still challenging issues for a facile hydrothermal method. ${ }^{67,68,70-75}$ In this study, it can be seen that with an increasing in the Au buffer thickness that both the length and diameter of the $\mathrm{ZnO} / \mathrm{ZnSe}$ NRs change. The length and diameter of the NRs change in the range of 1.79-2.08 $\mu \mathrm{m}$ and 50-100 nm, respectively, in accordance with increasing Au buffer layer thickness. It is expected that the diameter of the NRs mainly depends on the nature of the $\mathrm{ZnO}$ seed layer. However, as the thickness of $\mathrm{Au}$ is increased, then the sizes of the granules/clusters of $\mathrm{Au}$ increase, compactly covering the $\mathrm{ZnO}$ seed layer (Fig. 2(b) and (c)). As a result, the diameter of the NRs grown on a thicker Au buffer layer is increased compared with those grown on an $\mathrm{Au}$ free $\mathrm{ZnO}$ seed layer. This
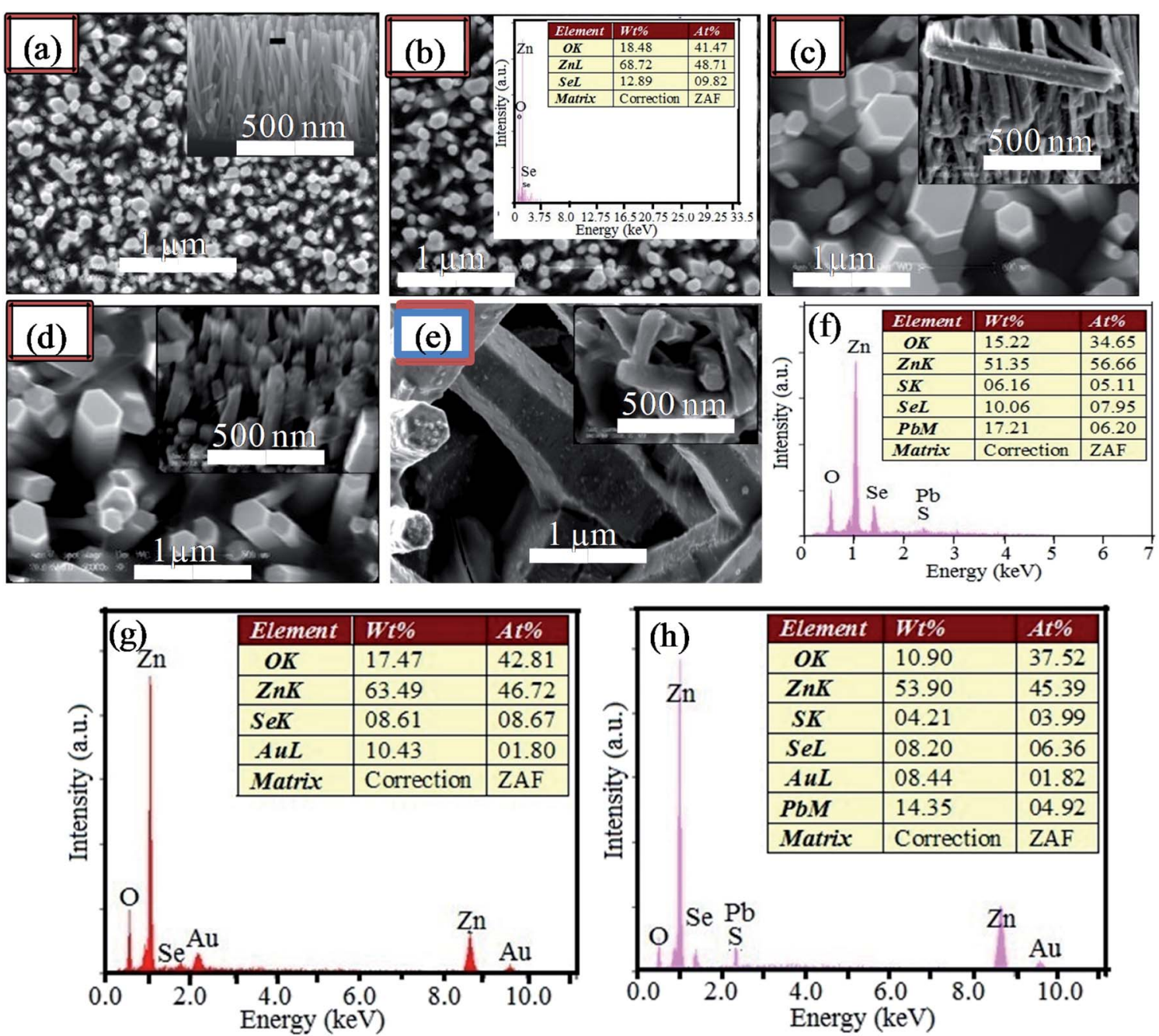

Fig. 3 Top and side views (inset) of the ZnO NR arrays grown on the ZnO seed layer (a). Top and side views of the ZnO/ZnSe core/shell NRAs grown on (b) Au@ZnO, Au =0.0 nm, (c) Au@ZnO, Au = $4.0 \mathrm{~nm}$, (d) Au@ZnO, Au = $8.0 \mathrm{~nm}$, and (e) Au@ZnO, Au =16.0 nm seed layers (scale bars for the top of $1 \mu \mathrm{m}$ and side of $500 \mathrm{~nm}$ ). EDX spectra of the $\mathrm{ZnO} / \mathrm{ZnSe} N R s$ (inset, (b)) and (f) ZnO/ZnSe/PbS QDs grown on an Au free ZnO seed layer. EDX spectra of (g) ZnO/ZnSe NRs and (h) ZnO/ZnSe/PbS QDs grown on an Au = $8.0 \mathrm{~nm}$ coated ZnO seed layer. 
change can be explained by the decrease in the nucleation agents of the $\mathrm{ZnO}$ seed layer for the growth of $\mathrm{ZnO} / \mathrm{ZnSe} \mathrm{NRs}$.

Fig. 3(b) (inset) shows the energy dispersive X-ray (EDX) spectrum of $\mathrm{ZnO} / \mathrm{ZnSe}$ core/shell NRs grown on an $\mathrm{Au}$ free $\mathrm{ZnO}$ seed layer. Three peaks of $\mathrm{Zn}, \mathrm{O}$ and Se can be observed, indicating that the grown $\mathrm{NR}$ array is $\mathrm{ZnO} / \mathrm{ZnSe}$. The EDX spectrum of the $\mathrm{ZnO} / \mathrm{ZnSe} / \mathrm{PbS}$ QD structure grown on the $\mathrm{Au}$ free $\mathrm{ZnO}$ seed layer is shown in Fig. 3(f). Four elemental peaks for Zn, O, $\mathrm{Se}, \mathrm{Pb}$ and $\mathrm{S}$ are present in the spectrum with proper stoichiometric percentages, confirming that ZnO NRs were uniformly coated with the $\mathrm{Se}, \mathrm{Pb}$ and $\mathrm{S}$ elements. The EDX spectra of the $\mathrm{ZnO} / \mathrm{ZnSe} \mathrm{NR}$ and $\mathrm{ZnO} / \mathrm{ZnSe} / \mathrm{PbS}$ QD structures grown on an $\mathrm{Au}$ coated ZnO seed layer are shown in Fig. 3(g) and (h). Importantly, an additional peak for Au can be seen in both spectra with proper stoichiometry, providing evidence that the $\mathrm{ZnO} /$ $\mathrm{ZnSe} \mathrm{NRs}$ and $\mathrm{ZnO} / \mathrm{ZnSe} / \mathrm{PbS}$ QDs have been grown on the Au coated $\mathrm{ZnO}$ seed layer.

\subsection{Transmission electron microscopy (TEM)}

Fig. 4A (left side) shows a low resolution image of intrinsic $\mathrm{ZnO}$ NRs (Fig. 4A(a)) and core/shell ZnO/ZnSe (Fig. 4A(b)), selected area electron diffraction (SAED) of $\mathrm{ZnO} / \mathrm{ZnSe}$ (Fig. 4A(c)) and a high-resolution transmission electron microscopy (HRTEM) image of the $\mathrm{ZnO} / \mathrm{ZnSe} / \mathrm{PbS}$ QDs (Fig. 4A(d)). From Fig. 4A(a), it can be clearly seen that the single ZnO NR possesses a diameter of less than $100 \mathrm{~nm}$. The $\mathrm{ZnO} / \mathrm{ZnSe}$ consists of a core/shell-like structure, which is indicated by an arrow (Fig. 4A(b)). The SAED image of $\mathrm{ZnO} / \mathrm{ZnSe}$ exhibits that the grown NR is single crystalline in nature (Fig. 4A(c)). The HRTEM shows a well-defined lattice fringe separation of $\sim 5.13 \mathrm{~nm}$ corresponding to the lattice constant ' $c$ ', meaning that the NRs have grown along the $c$-axis. This result indicates that the NRs have a high quality single-crystalline structure with a growth orientation along the [0001] direction, which is in good agreement with the SAED and XRD results. In addition, the d-spacing in between the crystal planes is about $\sim 2.67 \mathrm{~nm}$, which is good agreement with the XRD results (Fig. 1A and B). Fig. 4B(a/) and (b/) shows TEM images of $\mathrm{ZnO}$ and $\mathrm{ZnO} / \mathrm{ZnSe}$ grown on an $\mathrm{Au}=8.0 \mathrm{~nm}$ coated $\mathrm{ZnO}$ seed layer. The SAED and HRTEM results of the $\mathrm{ZnO} / \mathrm{ZnSe} / \mathrm{PbS}$ QDS are shown in Fig. $4 \mathrm{~B}(\mathrm{c} /)$ and $(\mathrm{d} /)$. In Fig. $4 \mathrm{~B}(\mathrm{~d} /)$, an area is enclosed by a white dotted line, which shows the average size of the PbS QDs. After analysis of the HRTEM, it can be concluded that a synthesized PbS QD size of $\sim 5.75 \mathrm{~nm}$ with a lattice constant of $\sim 0.24 \mathrm{~nm}$ was adsorbed on the $\mathrm{ZnO} / \mathrm{ZnSe}$ core/shell NRA photoelectrode.

Fig. $4 \mathrm{~B}(\mathrm{a} /)-(\mathrm{d} /)$ show TEM images of the $\mathrm{ZnO} / \mathrm{ZnSe}$ and $\mathrm{ZnO} /$ $\mathrm{ZnSe} / \mathrm{PbS}$ structures grown on an $\mathrm{Au}(\mathrm{Au}=8 \mathrm{~nm})$ coated $\mathrm{ZnO}$ seed layer. In this case, it can be seen that the core-shell $(\mathrm{ZnO} /$ $\mathrm{ZnSe}$ ) morphology is rougher (Fig. $4 \mathrm{~B}(\mathrm{~b} /)$ ) than when grown on the $\mathrm{Au}$ free $\mathrm{ZnO}$ seed layer (Fig. $4 \mathrm{~A}(\mathrm{~b})$ ). The SAED pattern (Fig. $4 \mathrm{~B}(\mathrm{c} /)$ ) and HRTEM lattice fringes (Fig. $4 \mathrm{~B}(\mathrm{~d} /)$ ) show small changes that can be attributed to the coating of $\mathrm{Au}$ on the $\mathrm{ZnO}$ seed layer. However, the photoelectrode consists of a $\mathrm{ZnO} / \mathrm{ZnSe} /$ $\mathrm{PbS}$ QS structure, which is indicated by different white symbols (QD = white circle area, $\mathrm{ZnSe}=$ parallelogram area, $\mathrm{ZnO}=$ straight line with lattice constants).

\subsection{Optical properties (absorption)}

Fig. 5 shows the absorption spectra of the ZnO NRAs, $\mathrm{ZnO} / \mathrm{ZnSe}$ (core/shell) NRAs and NRA density variation in the $\mathrm{ZnO} / \mathrm{ZnSe} /$ $\mathrm{PbS}$ QDs. The inset digital image shows changes in color
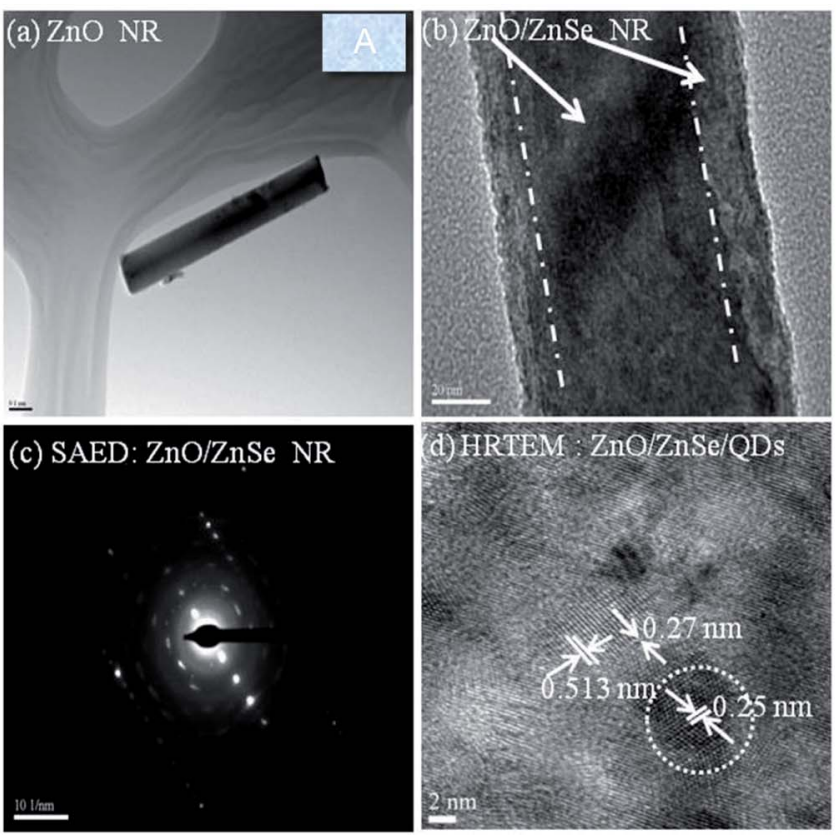
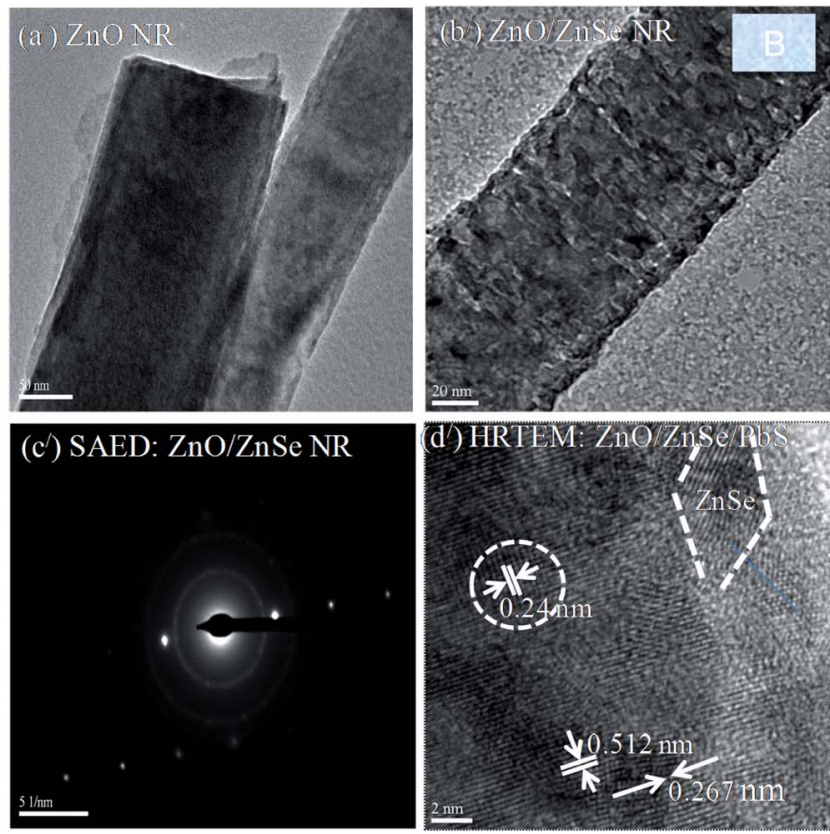

Fig. 4 (A) TEM images (left side) of (a) pure ZnO NRs, and (b) core-shell ZnO/ZnSe NRs, (c) SAED pattern of the ZnO/ZnSe NRs and (d) HRTEM image of the $\mathrm{ZnO} / \mathrm{ZnSe} / \mathrm{PbS}$ QDs grown on an Au free $\mathrm{ZnO}$ seed layer. (B) TEM images of $\left(a^{\prime}\right)$ pure $\mathrm{ZnO} N R s$, and $\left(\mathrm{b}^{\prime}\right)$ core-shell $\mathrm{ZnO} / \mathrm{ZnSe} \mathrm{NRs}$, $\left(c^{\prime}\right)$ SAED pattern of the $\mathrm{ZnO} / \mathrm{ZnSe} N R s$ and $\left(\mathrm{d}^{\prime}\right)$ HRTEM image of $\mathrm{ZnO} / \mathrm{ZnSe} / \mathrm{PbS}$ QDs grown on an Au $=8.0 \mathrm{~nm}$ coated $\mathrm{ZnO} \mathrm{ZnO}$ seed layer. 
associated with the changes in the structures. From Fig. 5 (inset), it can be seen that the ZnO NRAs exhibit (white), ZnO/ ZnSe NRs (orange) and $\mathrm{ZnO} / \mathrm{ZnSe} / \mathrm{PbS}$ QDs (black), respectively. The absorption edge of $\mathrm{ZnO}$ is located at around $380 \mathrm{~nm}$ and exhibits less absorption of light. However, the $\mathrm{ZnO} / \mathrm{ZnSe}$ core/shell NRAs demonstrate that more light can comparatively be absorbed than for the ZnO NRAs. The absorption edge is shifted toward a higher wavelength, which lowers the band gap of the $\mathrm{ZnO} / \mathrm{ZnSe}$ NRAs. Therefore, the optical absorption of $\mathrm{ZnO}$ can be enhanced by creating a ZnSe shell or more defects (e.g., metal ions doping) on the pure ZnO NRA surfaces.

In this case, large numbers of hole-electron pairs could be generated even without the presence of UV light. ${ }^{76}$ Hence, the efficiency of the $\mathrm{ZnO} / \mathrm{ZnSe} \mathrm{NR}$ array based solar cell can be increased. It is interesting that the absorption is significantly enhanced in the visible to near infrared region $(630-910 \mathrm{~nm}$ ) for the $\mathrm{ZnO} / \mathrm{ZnSe} / \mathrm{PbS}$ QD structure, which can be attributed to the $\mathrm{PbS}$ QDs. This value gradually decreases with a decrease in the ZnO/ZnSe NRA density, implying that fewer QDs are loaded into

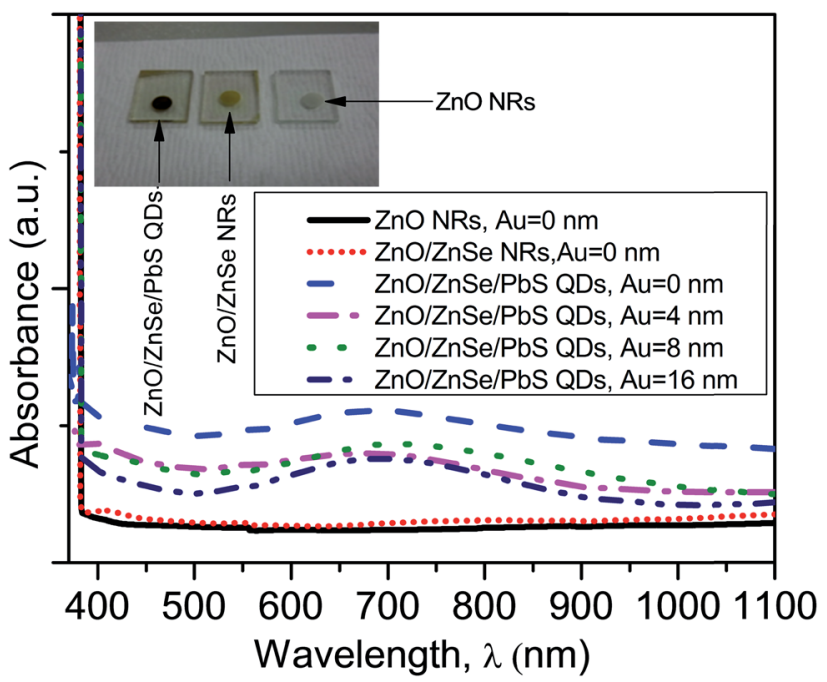

Fig. 5 The absorption spectra in the wavelength range of 370$1100 \mathrm{~nm}$ of the pure ZnO NRs, and ZnO/ZnSe NRs/PbS QDs with increasing $\mathrm{Au}(\mathrm{Au}=0.0,4.0,8.0$ and $16.0 \mathrm{~nm})$ thickness. lower $\mathrm{ZnO} / \mathrm{ZnSe} \mathrm{NR}$ array density surfaces. The band gap of the PbS QDs was found to be $\sim 1.75 \mathrm{eV}$, which is in good agreement with the reported value. ${ }^{58}$ The enhancement in the optical ability of the $\mathrm{ZnO} / \mathrm{ZnSe} / \mathrm{PbS}$ QD photoelectrode in the visible to near infrared region, making it promising for application in photovoltaic devices.

\section{$3.5 \quad J-V$ characteristics}

In an earlier publication, the solar cell performance for a specified NRA density was reported. ${ }^{58}$ Fig. 6(a) shows a prototype ZnO NR-based QDSC for electron-hole pair generation and their transport mechanism in the device. The solar cell consists of $\mathrm{ZnO} / \mathrm{ZnSe}$ (core/shell) NR arrays, QD sensitizer, polysulfide electrolyte and a counter electrode. In this case, the $\mathrm{ZnO} / \mathrm{ZbSe}$ NR arrays serve as a backbone for direct electron transport providing short transport distances in the $\mathrm{ZnO} / \mathrm{ZnSe} / \mathrm{PbS}$ QDS solar cell. Under the illumination of light, photons are captured by $\mathrm{PbS}$ QDs yielding electron-hole pairs that are rapidly separated into electrons and holes at the interface between the $\mathrm{ZnO}$ / ZnSe NRs and PbS QDs. The electrons are quickly injected into the conduction band of $\mathrm{ZnSe}$ then into $\mathrm{ZnO}$ and the holes are released by redox couples $\left(\mathrm{S}^{2-} / \mathrm{Sn}^{2-}\right)$ in the electrolyte.

Fig. 6(b) shows the photocurrent density $(J)$-voltage $(V)$ characteristics of the ZnO NRs/PbS QDs and NR array density variation of the $\mathrm{ZnO} / \mathrm{ZnSe} / \mathrm{PbS}$ QDs solar cells. The photoelectrode performance parameters such as short-circuit current density $\left(J_{\mathrm{SC}}\right)$, open-circuit voltage $\left(V_{\mathrm{OC}}\right)$, fill factor $(\mathrm{FF})$, efficiency $(\eta)$, series resistance $\left(R_{\mathrm{S}}\right)$ and shunt resistance $\left(R_{\mathrm{sh}}\right)$ for all of the devices are summarized in Table 1. From Fig. 6(b) (black line) and Table 1, it can be clearly seen that the ZnO NR-based solar cell fabricated as a $\mathrm{ZnO} / \mathrm{PbS} \mathrm{QD}$ device performed poorly with values of $\eta=0.079 \%$, $J_{\mathrm{SC}}=7.92 \mathrm{~mA} \mathrm{~cm}^{-2}$ and $V_{\mathrm{OC}}=0.04 \mathrm{~V}$, which could be due to its inability to capture more photons, resulting in the generation of fewer electron-hole pairs. The obtained results are consistent with the absorption phenomenon of the ZnO NR arrays shown in Fig. 5, in that the cell can absorb fewer photons in the visible region. It is interesting that the performance of the $\mathrm{ZnO} / \mathrm{ZnSe}$ core/shell NRbased devices ( $\mathrm{ZnO}$ NRs coated $\mathrm{ZnSe}$ ) is significantly enhanced compared to that of ZnO NR-based devices (Table 1) and the solar cell parameters change with the variation in the $\mathrm{ZnO} / \mathrm{ZnSe} \mathrm{NRA}$
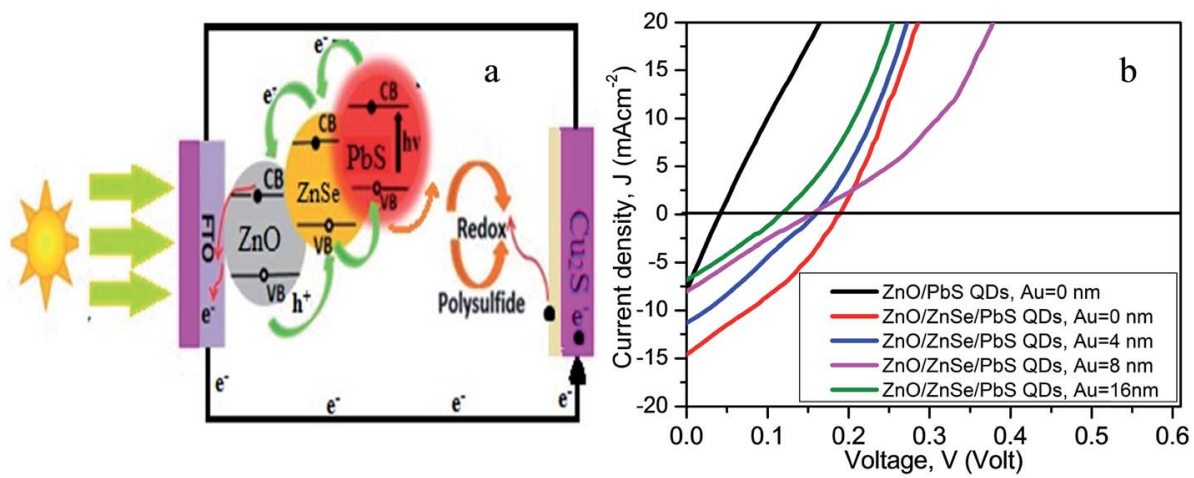

Fig. 6 (a) Electron-hole transport mechanism [ref. 58], and (b) the J-V characteristics of the glass/FTO/ZnO/PbS QDs (black line) and ZnO/ZnSe NRA density varying glass/FTO/ZnO/ZnSe NRs/PbS QD solar cells. 
Table $1 J_{\mathrm{SC}}, V_{\mathrm{OC}}, \mathrm{FF}, \mathrm{PCE}, R_{\mathrm{S}}$ and $R_{\mathrm{sh}}$ values of the devices

\begin{tabular}{lcllrr}
\hline Device name & $J_{\text {SC }}\left(\mathrm{mA} \mathrm{cm}^{-2}\right)$ & $V_{\text {OC }}($ volt $)$ & FF & $\eta(\%)$ & $R_{\mathrm{s}}(\mathrm{ohm})$ \\
\hline ZnO/PbS QDs, Au $=0 \mathrm{~nm}$ & 7.92 & 0.04 & 0.252 & 0.079 & 4.202 \\
ZnO/ZnSe/PbS QDs, Au $=0 \mathrm{~nm}$ & 14.60 & 0.19 & 0.312 & 0.876 & 0.730 \\
ZnO/ZnSe/PbS QDs, Au $=4 \mathrm{~nm}$ & 11.30 & 0.16 & 0.270 & 0.487 & 0.373 \\
ZnO/ZnSe/PbS QDs, Au $=8 \mathrm{~nm}$ & 8.01 & 0.155 & 0.235 & 0.291 & 0.804 \\
ZnO/ZnSe/PbS QDs, Au $=16 \mathrm{~nm}$ & 6.76 & 0.13 & 0.282 & 0.247 & 1.004
\end{tabular}

density (Fig. 6(b)). As the ZnSe (shell) is coated on the ZnO NRs (core), the band gap of $\mathrm{ZnO} / \mathrm{ZnSe}$ is reduced and the surface defects are suppressed, consequently leading to the more effective absorption of photons. ${ }^{54-58}$ The PbS QD solar cell assembled using the highest $\mathrm{ZnO} / \mathrm{ZnSe}$ NRA density exhibits a high performance of $\eta=0.88 \%, J_{\mathrm{SC}}=14.60 \mathrm{~mA} \mathrm{~cm}{ }^{-2}, V_{\mathrm{OC}}=0.19 \mathrm{~V}$ and $\mathrm{FF}=0.32$. Compared with the $\mathrm{ZnO}$ NR photoelectrode, the $\mathrm{ZnO} / \mathrm{ZnSe} \mathrm{NR}$ photoelectrode displays significantly enhanced $\eta, J_{\mathrm{SC}}, V_{\mathrm{OC}}$ and $\mathrm{FF}$ values, which could be due to an increase in the efficiency of QD loading, suppression of surface defects, reduction in electron loss and decrease in the band gap of $\mathrm{ZnO} / \mathrm{ZnSe}^{.5-58} \mathrm{The}$ assembled QD device with the highest density of $\mathrm{ZnO} / \mathrm{ZnSe}$ NRAs not only shows improved charge transport phenomena but also allows for the efficient loading of QDs to provide more active sites for generating large numbers of electron-hole pairs and to catalyze the reduction of $\mathrm{Sn}^{2-}$ to $\mathrm{nS}^{2}$, hence enhancing the efficiency of the device..$^{54-56,77}$ The improved morphology of the $\mathrm{ZnO} / \mathrm{ZnSe}$ NRs offers efficient transport channels to ensure the rapid transportation of electrons due to band gap lowering, and thus the charge combination process can be suppressed, also leading to an increase in performance. ${ }^{55-58}$ As the density of the $\mathrm{ZnO} / \mathrm{ZnSe}$ NRAs decreases, the photovoltaic performance decreases, which can be attributed to a decrease in the surface area for QD loading (shown in Fig. 3(b) and Table 1) and the production of too many defects, resulting in electron loss. The solar cell parameters for the PbS QD device with the lowest $\mathrm{ZnO} / \mathrm{ZnSe}$ NRA density were obtained as $\eta=0.25 \%, J_{\mathrm{SC}}$ $=6.76 \mathrm{~mA} \mathrm{~cm}^{-2}, V_{\mathrm{OC}}=0.13 \mathrm{~V}$ and $\mathrm{FF}=0.28$ (Table 1). The lower value of $V_{\mathrm{OC}}$ for the lowest $\mathrm{ZnO} / \mathrm{ZnSe} \mathrm{NR}$ array density can be attributed to the existence of large defects.

From Table 1 it is obvious that the $\mathrm{ZnO} / \mathrm{ZnSe} / \mathrm{PbS}$ QD solar cells possess higher $\left(V_{\mathrm{OC}}\right)$ and large short-circuit current densities $\left(U_{\mathrm{sC}}\right)$ than those of the $\mathrm{ZnO} / \mathrm{PbS}$ QD solar cell. The enhancement in the $V_{\mathrm{OC}}$ values of the $\mathrm{ZnO} / \mathrm{ZnSe} / \mathrm{PbS}$ QD solar cells can be attributed to the increase in the adsorption and decrease in defects as a result of surface modification. Therefore, the performance of $\mathrm{ZnO} / \mathrm{ZnSe}$-based $\mathrm{QD}$ devices is enhanced via changes in the surface characteristics of the $\mathrm{ZnO}$ NRAs for the harvesting of incident photons and for suppressing surface charge recombination. However, the value of $J_{\mathrm{SC}}$ decreases with decreasing $\mathrm{ZnO} / \mathrm{ZnSe}$ NRA density, which can be attributed to lower interfacial area resulting in decreased light harvesting (Table 1).

The efficiency of the highest $\mathrm{ZnO} / \mathrm{ZnSe}$ NRA density is enhanced by $\sim 82 \%$ compared to the lowest NRA density via enlarging of the interfacial area between the NR arrays and $\mathrm{PbS}$ QDs. A notable efficiency of $\sim 0.88 \%$ was attained for the highest NRA density, while the efficiency of ZnO/ZnSe NRAs decreased with decreasing NR density suggesting that the dimension of free space between $\mathrm{ZnO} / \mathrm{ZnSe}$ is also crucial for the infiltration of PbS QDs into the NR array system. It is reported that vertical nanostructures, especially low denser arrays of NRs/NWs, may not be optimal for light-harvesting because some photons can fall into the gap between adjacent nanorods and the light loss could be significant, ${ }^{78}$ while denser NR arrays of long and thin single-crystalline nanorods would be ideal to obtain a higher surface and higher electron transport. ${ }^{79}$

The fill factor $(\mathrm{FF})$ and the shunt resistance $\left(R_{\mathrm{sh}}\right)$ values of the $\mathrm{ZnO} / \mathrm{ZnSe}$ NR solar cells also improved over those of the $\mathrm{ZnO}$ NR-based solar cell, which can be attributed to a decrease in surface defects or recombination centers. The fill factor $(\mathrm{FF})$ value is related to the $R_{\mathrm{sh}}$ value according to eqn (4): $:^{77}$

$$
\mathrm{FF}=\mathrm{FF}_{0}\left(1-\frac{1}{R_{\mathrm{sh}}}\right)
$$

where $\mathrm{FF}_{0}$ is the theoretical maximum fill factor. From Table 1 it can be inferred that the FF increases for the $\mathrm{ZnO} / \mathrm{ZnSe}$ QDSC as a result of an increase in the $R_{\mathrm{sh}}$ value. Following previous discussions, it is evident that the modification of the ZnO NRs using a ZnSe shell contributes towards improving the $J_{\mathrm{SC}}, \mathrm{FF}$ and $V_{\mathrm{OC}}$ values of the $\mathrm{ZnO} / \mathrm{ZnSe} / \mathrm{PbS}$ QD solar cells.

Our findings suggest that the possible formation of a $\mathrm{ZnO} /$ ZnSe nanostructure material grown via facile hydrothermal and ion exchange methods could be used for QD sensitized solar cell applications.

The drawback of this type of solar cell is the rather poor $V_{\mathrm{OC}}$, fill factor and inferior device efficiency values, which limit the energy conversion efficiency. These poor values of the solar cell factors could be improved by increasing the hole recovery rate of the polysulfide electrolyte, leading to a higher probability of charge recombination, ${ }^{80}$ increase in the quality of the counter electrode and decrease in the surface defects of the $\mathrm{ZnO} / \mathrm{ZnSe}$ nanostructure. Furthermore, to improve the efficiency of NR array-based devices, the structures of $\mathrm{ZnO} / \mathrm{ZnSe}$ and the size of QDs should be optimized, and a new hole transport medium with a suitable redox potential and low electron recombination at the semiconductor and electrolyte interface should be developed.

\section{Conclusions}

Utilizing hydrothermal and ion exchange approaches, $\mathrm{ZnO} /$ ZnSe nanostructures can be controlled using a Au buffer layer deposited on a $\mathrm{ZnO}$ seed layer. It is found that the $\mathrm{ZnO} / \mathrm{ZnSe}$ nanostructure array density plays an important role in the 
light-harvesting performance. The absorption increases with an increase in the $\mathrm{ZnO} / \mathrm{ZnSe}$ core/shell NRA density and significant enhancement is observed in the visible to near infrared region. The infiltration of $\mathrm{PbS}$ QDs into the $\mathrm{ZnO} / \mathrm{ZnSe}$ core/shell structure with the highest NR array density leads to a maximum PCE of $\sim 0.88 \%$, and the efficiency decreases with a decrease in the $\mathrm{ZnO} / \mathrm{ZnSe}$ core/shell NRA density. Indeed, the intrinsic $\mathrm{ZnO} / \mathrm{PbS}$ QD solar cell exhibits low efficiency, but controlling the morphology of the $\mathrm{ZnO} / \mathrm{ZnSe}$ NRA improves the device efficiency. It can be seen that the $V_{\mathrm{OC}}, \mathrm{FF}$ and $J_{\mathrm{SC}}$ values depend on the morphology variation of the $\mathrm{ZnO} / \mathrm{ZnSe}$ NRAs, which is an important factor that can be used to improve the device performance. Although the efficiency in the present study is very low, further improvement of the $\mathrm{ZnO} / \mathrm{ZnSe} / \mathrm{PbS}$ QD photoelectrode could be achieved via the optimization of the rod-to-rod spacing, length, diameter, density, and the quality of the $\mathrm{ZnO} / \mathrm{ZnSe} \mathrm{NRs}$, counter electrode, and electrolyte, as well as the suppression of surface defects. In addition, the size of the PbS QDs should be optimized to harvest sunlight efficiently. The interface area between the QDs and nanostructured metal oxide, wherein the depletion region is formed, must also be as large as possible to create better carrier pathways.

\section{Conflicts of interest}

There are no conflicts of interest in the present study.

\section{Acknowledgements}

The author would like to thank the City University of Hong Kong for helping with the measurements.

\section{References}

1 S. E. Shaheen, D. S. Ginley and G. E. Jabbour, MRS Bull., 2005, 30, 10.

2 H. Tada, M. Fujishima and H. Kobayashi, Chem. Soc. Rev., 2011, 40, 4232-4243.

3 P. K. Santra and P. V. Kamat, J. Am. Chem. Soc., 2012, 134, 2508-2511.

4 M. A. Hossain, J. R. Jennings, Z. Y. Koh and Q. Wang, ACS Nano, 2011, 5, 3172-3181.

5 J. Ryu, S. H. Lee, D. H. Nam and C. B. Park, Adv. Mater., 2011, 23, 1883-1888.

6 H. C. Zhao, J. P. Harney, Y. T. Huang, J. H. Yum, M. K. Nazeeruddin, M. Gratzel, M. K. Tsai and J. Rochford, J. Inorg. Chem., 2012, 51, 1-3.

7 P. G. Johansson, J. G. Rowley, A. Taheri and G. J. Meyer, Langmuir, 2011, 27, 14522-14531.

8 M. Kamruzzaman and J. A. Zapien, J. Nanosci. Nanotechnol., 2017, 17, 5342-5351.

9 M. Kamruzzaman and J. A. Zapien, J. Nanosci. Nanotechnol., 2017, 17, 5061-5072.

10 B. A. Gonfa, M. R. Kim, N. Delegan, A. C. Tavares, R. Izquierdo, N. Wu, M. A. El Khakani and D. Ma, Nanoscale, 2015, 7, 10039-10049.
11 S. Shi, Y. Li, X. Li and H. Wang, Mater. Horiz., 2015, 2, 378405.

12 H. Zhang, J. Mao, H. He, D. Zhang, L. Zhu, F. Xie, K. S. Won, M. Grätzel and W. C. H. Choy, Adv. Energy Mater., 2015, 5, 1501354.

13 K. W. J. Barnham and G. Duggan, J. Appl. Phys., 1990, 67, 3490.

14 B. O'Regan and M. Gratzel, Nature, 1991, 353, 737-740.

15 S. Mathew, A. Yella, P. Gao, R. Humphry-Baker, F. E. Curchod Basile, N. Ashari-Astani, I. Tavernelli, U. Rothlisberger, M. D. K. Nazeeruddin and M. Grätzel, Nat. Chem., 2014, 6, 242-247.

16 J. Du J, Z. Du, J. S. Hu, Z. Pan, Q. Shen, J. Sun, D. Long, H. Dong, L. Sun L, X. Zhong and L. J. Wan, J. Am. Chem. Soc., 2016, 138, 4201-4209.

17 A. H. Ip, S. M. Thon, S. Hoogland, O. Voznyy, D. Zhitomirsky, R. Debnath, L. Levina, L. R. Rollny, G. H. Carey, A. Fischer, K. W. Kemp, I. J. Kramer, Z. Ning, J. Labelle, K. Chou, A. Amassian and E. H. Sargent, Nat. Nanotechnol., 2016, 7, 9. 18 P. V. Kamat, J. Phys. Chem. Lett., 2013, 4, 908-918.

19 J. M. Luther, J. Gao, M. T. Lioyd, Q. E. Semonin, M. C. Beard and A. J. Nozik, Adv. Mater., 2010, 22, 3704-3707.

20 J. Tang, W. K. Kyle, S. Hoogland, S. K. Jeong, H. Liu, L. Levina, M. Furukawa, X. Wang, R. Debnath, D. Cha, W. K. Chou, A. Fischer, A. Amassian, B. J. Asbury and H. E. Sargent, Nat. Mater., 2011, 10, 765-771.

21 D. Zhitomirsky, O. Voznyy, L. Levina, S. Hoogland, W. K. Kemp, H. A. Ip, M. S. Thon and H. E. Sargent, Nat. Commun., 2014, 5, 3803.

22 M. C. H. Chuang, R. P. Brown, V. Bulović and G. M. Bawendi, Nat. Mater., 2014, 3984, 1-6.

23 Z. Ning, O. Voznyy, J. Pan, S. Hoogland, V. Adinolfi, J. Xu, M. Li, R. A. Kirmani, J. P. Sun, J. Minor, K. W. Kemp, D. Dong, L. Rollny, A. Labelle, G. Carey, B. Sutherland, I. Hill, A. Amassian, H. Liu, J. Tang, O. M. Bakr and H. E. Sargent, Nat. Mater., 2014, 4007, 1-7.

24 Y. Chen, W. Fu and P. Lv, Appl. Mech. Mater., 2014, 448-453, 1433-1436.

25 S. Gorer and G. Hodes, J. Phys. Chem., 1994, 98, 5338-5346. 26 W. W. Yu, L. Qu, W. Guo and X. Peng, Chem. Mater., 2003, 15, 2854-2860.

27 J. B. Sambur, T. Novet and B. A. Parkinson, Science, 2010, 330, 63-66.

28 W. A. Tisdale, K. J. Williams, B. A. Timp, D. J. Norris, E. S. Aydil and X. Y. Zhu, Science, 2010, 328, 1543-1547.

29 Z. Yang, C. Y. Chen, P. Roy and H. T. Chang, Chem. Commun., 2011, 47, 9561-9571.

30 C. Y. Luan, A. Vaneski, A. S. Susha, X. Xu, H. En Wang, X. Chen, J. Xu, W. J. Zhang, C. S. Lee, A. L. Rogach and J. A. Zapien, Nanoscale Res. Lett., 2011, 6, 340.

31 L. Luo, G. Lv, B. Li, X. Hu, J. Lei, J. Wang and Y. Tang, Thin Solid Films, 2010, 518, 5146-5152.

32 P. Yu, K. Zhu, A. G. Norman, S. Ferrere, A. J. Frank and A. J. Nozik, J. Phys. Chem. B, 2006, 110, 25451-25454.

33 H. McDaniel, N. Fuke, S. N. Makarov, M. J. Pietryga and I. V. Klimov, Nat. Commun., 2013, 4(2887), 1-10. 
34 N. McElroy, D. Espinbarro-Valazquez, E. Lewis, S. Haigh, P. O'Brien and D. J. Binks, Thin Solid Films, 2014, 560, 65-70.

35 M. A. Abbas, M. A. Basit, T. J. Park and J. H. Bang, Phys. Chem. Chem. Phys., 2015, 17, 9752-9760.

36 W. Lee, S. K. Min, V. Dhas, S. B. Ogale and H. S. Hwan, Electrochem. Commun., 2009, 11, 103-106.

37 J. B. Baxter and E. S. Aydil, Appl. Phys. Lett., 2005, 86, 053114.

38 P. Ravirajan, A. M. Peiro, M. K. Nazeeruddin, M. Gratzel, D. D. C. Bradely, J. R. Durrant and J. Nelson, J. Phys. Chem., 2006, 110, 7635-7639.

39 Y. F. Hsu, Y. Y. Xi, A. Djurisic and W. K. Chen, Appl. Phys. Lett., 2008, 92, 133507.

40 L. Yu, J. Jia, G. Yi and M. Han, RSC Adv., 2016, 6, 33279.

41 R. J. Ellingson, M. C. Beard, J. C. Johnson, P. Yu, O. I. Micic, A. J. Nozik, A. Shabaev and A. L. Efros, Nano Lett., 2005, 5, 865-871.

42 M. Khan, C. Wei, M. Chen, J. Tao, N. Huang, Z. Qi and L. Li, J. Alloys Compd., 2014, 612, 306-314.

43 A. A. Kumar, S. K. N. Kumar, A. A. Aniley, R. E. Fernandez and S. Bhansali, J. Electrochem. Soc., 2019, 166, B3264B3270.

44 I. Elkamel, N. Hamdaoui, A. Mezni, R. Ajjel and L. Beji, J. Mater. Sci.: Mater. Electron., 2019, 30, 9444-9454.

45 V. T. Duoc, D. T. T. Le, N. D. Hoa, N. V. Duy, C. M. Hung, H. Nguyen and N. V. Hieu, J. Nanomater., 2019, 6821937.

46 D. Calestani, M. Villani, M. Culiolo, D. Delmonte, N. Coppedè and A. Zappettini, Sens. Actuators, B, 2017, 245, 166-170.

47 P. Fakhri, B. Amini, R. Bagherzadeh, M. Kashfi, M. Latifi, N. Yavari, S. A. Kanice and L. Kong, RSC Adv., 2019, 9, 10117. 48 F. Khan, W. Khan and S. D. Kim, Nanomaterials, 2019, 9, 440. 49 D. C. Olson, Y. J. Lee, M. S. White, N. Kopidakis, S. E. Shaheen, D. S. Ginley, J. A. Voigt and J. W. P. Hsu, J. Phys. Chem. C, 2007, 111, 16640-16645.

50 J. J. Tian, Q. F. Zhang, E. Uchaker, R. Gao, X. H. Qu, S. E. Zhang and G. Z. Cao, Energy Environ. Sci., 2013, 6, 3542.

51 Y. Y. Bu, Z. Y. Chen, W. B. Li and J. Q. Yu, ACS Appl. Mater. Interfaces, 2013, 5, 5097.

52 X. P. Qi, G. W. She, Y. Y. Liu, L. X. Mu and W. S. Shi, Chem. Commun., 2012, 48, 242.

53 H. N. Chen, W. P. Li, H. C. Liu and L. Q. Zhu, Electrochem. Commun., 2011, 13, 331.

54 C. Ding, Y. Zhang, F. Liu, Y. Kitabatake, S. Hayase, T. Toyoda, R. Wang, K. Yoshino, T. Minemoto and Q. Shen, Nanoscale Horiz., 2018, 3, 417-429.

55 M. L. Zhang, F. Jin, M. L. Zheng, J. Liu, Z. S. Zhao and X. M. Duan, RSC Adv., 2014, 4, 10462.

56 F. Zhang, X. Han, S. T. Leeb and B. Sun, J. Mater. Chem., 2012, 22, 5362 .
57 X. Song, M. Wang, J. Deng, Y. Ju, T. Xing, J. Ding, Z. Yang and J. Shao, J. Power Sources, 2014, 269, 661-670.

58 M. Kamruzzaman and J. A. Zapien, J. Nanopart. Res., 2017, 19, 125-136.

59 K. M. Coakley, B. S. Srinivasan, J. M. Ziebarth, C. Goh, Y. Liu and M. D. McGehee, Adv. Funct. Mater., 2005, 15, 1927.

60 V. Chakrapani, D. Baker and P. V. Kamat, J. Am. Chem. Soc., 2011, 133, 9607-9615.

61 M. Kamruzzaman and J. A. Zapien, Crystallogr. Rep., 2018, 63, 456-471.

62 S. Xu and Z. L. Wang, Nano Res., 2011, 4, 1013.

63 J. Xu J, C. Y. Luan, Y. B. Tang, X. Chen, J. A. Zapien, W. J. Zhang, H. L. Kwong, X. M. Meng, S. T. Lee and C. S. Lee, ACS Nano, 2010, 4, 6064-6070.

64 L. Yu, J. Jia, G. Yi G and M. Han, RSC Adv., 2016, 6, 33279.

65 Joint Committee on Powder Di_raction Standards, Powder Diffraction File, (Philadel-phia, PA: ASTM, 1967). Card 0361451 (for $\mathrm{ZnO}$ hexagonal) and 40831 (for $\mathrm{Zn}$ hexagonal).

66 J. Y. Kwon, T. S. Yoon, K. B. Kim and S. H. Min, J. Appl. Phys., 2003, 93, 3270.

67 B. Weintraub, S. Chang, S. Singgamaneni, W. H. Lee, Y. J. Choi, J. H. Bae, M. Kirkham, V. V. Tsukruk and Y. Deng, Nanotechnology, 2008, 19, 435302.

68 H. Sun, M. Luo, W. Weng, K. Cheng, P. Du, G. Shen and G. Han, Nanotechnology, 2008, 19, 395602.

69 C. Y. Luan, K. T. Cheung, Y. Foo, L. Y. Yu, Q. Shen and J. A. Zapien, Proc SPIE 8987-627, Oxide-based Materials and Devices, 2014, p. 898725.

70 G. Sinha, L. E. Depero and I. Alessandri, ACS Appl. Mater. Interfaces, 2001, 3, 2557-2563.

71 X. D. Wang, J. H. Song and C. J. Summers, J. Phys. Chem. B, 2006, 110, 7720-7724.

72 J. B. Cui, C. P. Daghlian, U. J. Gibson, R. Pusche, P. Geithner and l. Ley, J. Appl. Phys., 2005, 97, 044315.

73 M. Mahanti and D. Basak, RSC Adv., 2014, 4, 15466.

74 S. H. Kim, C. S. Lee, J. Kim, J. W. Cho and Y. K. Kim, AIP Adv., 2013, 3, 092132.

75 S. Muthumari, G. Devi, P. Revathi, R. Ijayalakshmi R and C. Sanjeeviraja, J. Appl. Sci., 2012, 12, 1722-1725.

76 S. Sakthivel, B. Neppolian, M. V. Shankar, B. Arabindoo, M. Palanichamy and V. Murugesan, Sol. Energy Mater. Sol. Cells, 2003, 77, 65-82.

77 K. Park, Q. F. Zhang, B. B. Garcia and G. Z. Cao, J. Phys. Chem. C, 2011, 115, 4927-4934.

78 C. Y. Jiang, X. W. Sun, G. Q. Lo and D. L. Kwong, Appl. Phys. Lett., 2007, 90, 263501.

79 I. Gonzalez-Valls and M. Lira-Cantu, Energy Environ. Sci., 2009, 2, 19-34.

80 Y. L. Lee and C. H. Chang, J. Power Sources, 2018, 185, 584. 